\title{
Profil Penguasaan Konsep Tatanama Senyawa dan Persamaan Reaksi Pada Siswa Kelas XI IPA-4 SMA Negeri 2 Sampit Tahun Ajaran 2018/2019
}

\author{
Dwi Azarianti*, I Made Sadiana, Nopriawan Berkat Asi \\ Program Studi Pendidikan Kimia, Jurusan Pendidikan MIPA, FKIP, Universitas \\ Palangka Raya, Indonesia \\ E-mail:dwiazarianti@gmail.com
}

\begin{abstract}
ABSTRAK
Diterima: 05 Maret 2020; Disetujui: 20 Maret 2020; Diterbitkan: 26 Maret 2020

Konsep tatanama senyawa dan persamaan reaksi merupakan salah satu konsep kimia yang di ajarkan di SMA kelas X. Penelitian ini bertujuan untuk mendeskripsikan penguasaan konsep tatanama senyawa dan persamaan reaksi pada siswa kelas XI. Penelitian ini termasuk jenis penelitian kualitatif yang bersifat deskriptif. subjek penelitian ini adalah 30 siswa kelas XI IPA-4 SMA Negeri 2 Sampit tahun ajaran 2018/2019 yang sudah menerima pembelajaran tatanama senyawa dan persamaan reaksi. Data yang dikumpulkan berupa dokumen RPP yang didapat dari guru kimia, data penguasaan konsep siswa yang didapat melalui tes uraian dengan jumlah soal sebanyak 14 butir dari 4 indikator dan data hasil wawancara siswa. Hasil penelitian menunjukkan bahwa penguasaan konsep siswa pada topik tatanama senyawa dan persamaan reaksi siswa yaitu sebesar $74.18 \%$ berada pada kategori tinggi. Penguasaan konsep siswa terbagi kedalam 3 (tiga) kategori yaitu sangat tinggi, tinggi, dan sedang. Siswa pada kategori sangat tinggi berjumlah 9 siswa, siswa pada kategori tinggi berjumlah 12 siswa. Siswa pada kategori sedang berjumlah 9 siswa. Siswa mampu menuliskan rumus molekul dan rumus empiris suatu senyawa sebesar $81,66 \%$ dengan kategori tinggi, siswa mampu menuliskan nama senyawa anorganik dan senyawa organik sebesar 75,18\% dengan kategori tinggi, siswa mampu menuliskan rumus kimia senyawa anorganik sederhana dan senyawa organik sederhana sebesar $84,58 \%$ dengan kategori tinggi dan siswa mampu menjelaskan bagian-bagian dari suatu persamaan reaksi sebesar 47,92\% dengan kategori rendah.
\end{abstract}

Kata Kunci: penguasaan konsep, persamaan reaksi, tatanama senyawa

\section{PENDAHULUAN}

Pendidikan adalah usaha sadar dan terencana untuk mewujudkan suasana belajar dan proses pembelajaran agar peserta didik secara aktif mengembangkan potensi dirinya untuk memiliki kekuatan spiritual keagamaan, pengendalian diri, kepribadian, kecerdasan, akhlak mulia, serta keterampilan yang diperlukan dirinya, masyarakat, bangsa dan negara.

Ilmu kimia merupakan bagian dari ilmu pengetahuan alam yang mempelajari tentang sifat, struktur materi, komposisi materi, perubahan, dan energi yang menyertai perubahan energi (Ghalib, 2009). Dalam ilmu kimia terdapat dua jenis penguasaan yang harus dikuasai oleh siswa, yaitu penguasaan konseptual dan penguasaan algoritmik. Penguasaan konseptual merupakan penguasaan tentang hal-hal yang berhubungan dengan konsep, yaitu arti, sifat, dan 
uraian suatu konsep dan juga kemampuan dalam menjelaskan teks, diagram, dan (fenomena yang melibatkan konsep-konsep pokok yang bersifat abstrak dan teoriteori dasar sains. Penguasaan algoritmik merupakan penguasaan tentang prosedur atau serangkaian peraturan yang melibatkan perhitungan matematika untuk memecahkan suatu masalah. Siswa yang mendapatkan berbagai konsep dan konteks soal-soal kimia diharapkan dapat berhasil memahami dan menyelesaikan soal-soal kimia dengan pengetahuannya (Asi, 2018).

Ilmu kimia merupakan salah satu ilmu sains yang direpresentasikan ke dalam tiga level yaitu level makroskopik, level sub-mikroskopik, dan level simbolik. Level makroskopik berisi hal-hal nyata yang dapat diamati secara fisik, seperti fenomena kimia yang terjadi dalam kehidupan sehari-hari maupun fenomena di laboratorium. Level sub-mikroskopik berisi level partikel yang dapat digunakan untuk menggambarkan bentuk partikulat dari suatu fenomena kimia, misalnya pergerakan elektron, molekul, partikel, dan atom. Level simbolik adalah representasi berupa gambar, angka, huruf, dan simbol yang mewakili suatu kejadian, misalnya persamaan reaksi kimia dan grafik (Sulistyowati \& Poedjiastoeti, 2013).

Kimia merupakan salah satu pelajaran IPA yang berlaku pada kurikulum SMA. Mata pelajaran kimia ini merupakan mata pelajaran yang membutuhkan hafalan, hitungan, dan konsep. Tatanama senyawa dan persamaan reaksi kimia adalah salah satu mata pelajaran kimia di kelas X semester II. Mata pelajaran ini membutuhkan penerapan konsep dan hafalan sehingga memerlukan konsentrasi dan perhatian siswa dalam mengikuti mata pelajaran ini. Tatanama senyawa kimia dan persamaan kimia merupakan materi kimia yang bersifat abstrak yang memuat penguasaan konsep simbolik dan penguasaan algoritmik. Pembelajaran yang sering dilakukan selama ini hanya terfokus pada penggunaan algoritmik dalam mencapai tujuan pembelajaranya.

Materi tatanama senyawa dan persamaan reaksi adalah salah satu pokok bahasan yang dipelajari dalam mata pelajaran kimia di SMA/MA. Pada kurikulum 2013 pokok bahasan ini diajarkan pada kelas X SMA semester genap.

Menurut Hengki (2015) diketahui bahwa peningkatan penguasaan konsep tata nama senyawa jumlah siswa yang menjawab benar pada saat pretes $2,68 \%$ menjadi 74,12\% pada saat postes ; Selain itu hasil penelitian yang dilakukan Aulia (2014) diketahui bahwa secara keseluruhan visualisasi penguasaan siswa yang cenderung masih mengalami kesalahan dalam menjelaskan topik persamaan reaksi kimia, pada level makroskopik, mikroskopik, dan simbolik karena pada siswa telah memiliki penguasaan awal dan menjadi konsep yang berkembang dipenguasaan siswa.

Beberapa penelitian tersebut dilakukan dengan memberikan perlakuan kepada subjek penelitian berupa, dimana dalam penelitian tersebut peneliti berupaya meningkatkan hasil belajar siswa. Dengan demikian, hasil belajar siswa yang diperoleh tidak mampu merekontruksi kembali proses pembelajaran yang dilaksanakan oleh guru, sehingga tidak dapat menentukan apakah guru telah melaksanakan pembelajaran dengan baik dan apakah tujuan pembelajaran telah tercapai. Kekurangan inilah yang menjadi perhatian peneliti, dimana pada penelitian ini peneliti merekontruksi kembali proses pembelajaran yang guru berikan khususnya pada materi konsep tatanama senyawa dan persamaan reaksi. Peneliti mengumpulkan informasi dan menganalisis bagaimana penguasaan 
konsep siswa dari proses pembelajaran disekolah dengan pemberian tes tanpa diberikan suatu perlakuan terhadap subjek penelitian. Hasil tes terhadap subjek penelitian kemudian dikaitkan dengan RPP pembelajaran guru materi pembelajaran yang disampaikan dikelas serta konfirmasi guru terkait hasil tes yang diberikan kepada subjek penelitian. Analisis ini kemudian akan mampu mengetahui apakah pembelajaran yang dilangsungkan oleh guru telah mampu mencapai tujuan pembelajran tatanama senyawa dan persamaan reaksi yang diharapkan. Berdasarkan uraian tersebut, penelitian tertarik melakukan penelitian dengn judul "Profil Penguasaan Konsep Tatanama Senyawa Kimia dan Persamaan Reaksi pada Siswa Kelas XI SMA Negeri 2 Sampit Tahun Ajaran 2018/2019”. Penelitian serupa juga telah dilakukan oleh Oktavia (2019).

\section{METODOLOGI PENELITIAN}

Penelitian ini dilaksanakan di SMA Negeri 2 Sampit yang beralamat di jalan Gunung Kerinci, kelurahan Baamang Hilir, kecamatan Baamang, Kabupaten Kotawaringin Timur, Kalimantan Tengah. Adapun subjek penelitiannya adalah 30 siswa di kelas XI IPA-4 SMA Negeri 2 Sampit Tahun Ajaran 2018/2019. Pengambilan data dokumen RPP dilakukan pada bulan Mei 2018, tes penguasaan konsep tatanama senyawa dan persamaan reaksi dilakukan di SMA Negeri 2 Sampit pada hari Rabu tanggal 19 September 2018 di kelas XI IPA-4 dan diikuti 30 siswa sesuai dengan waktu yang digunakan saat pembelajaran kimia yaitu $2 \mathrm{x}$ 45 menit ( 2 jam pelajaran), dan wawancara siswa dilakukan pada 7 November 2018 .

Teknik analisis data dalam penelitian ini adalah data tes penguasaan konsep tatanama senyawa dan persamaan reaksi berupa hasil tes uraian yang dianalisis secara deskriptif dengan langkah-langkah sebagai berikut:

1. Jawaban siswa diberi skor sebagai data untuk mengetahui skor siswa sesuai dengan kriteria penskoran. Soal yang digunakan dalam penelitian ini berbentuk uraian yang berjumlah 14 butir soal. Hasil skor yang diperoleh digunakan untuk mendeskripsikan penguasaan konsep siswa tentang persamaan reaksi kimia. Penilaian sesuai dengan deskripsi penguasaan konsep siswa dalam tingkat penguasaan konsep tata nama senyawa kimia, dan persamaan reaksi yang disajikan pada lampiran 3 .

2. Total perolehan skor seluruh siswa digunakan untuk menentukan penguasaan konsep siswa secara keseluruhan menggunakan rumus:

$$
\text { Penguasaan konsep siswa }=\frac{\text { Jumlah skor jawaban yang diperoleh }}{\text { Jumlah skor total }} \times 100 \%
$$

3. Penguasaan konsep siswa dikategorisasi sesuai kriteria penguasaan konsep yang disarankan oleh Arikunto.

Tabel 1. Kriteria Penguasaan Konsep (Arikunto, 2007)

\begin{tabular}{cc}
\hline Penguasaan Konsep Siswa (\%) & Kategori \\
\hline $86-100$ & Sangat Tinggi \\
$66-85$ & Tinggi \\
$46-65$ & Sedang \\
$0-45$ & Rendah \\
\hline
\end{tabular}


4. Penguasaan konsep siswa dideskripsikan berdasarkan jawaban siswa pada masing-masing kategori tingkat penguasaan konsep siswa.

5. Penguasaan konsep merupakan rata-rata penguasaan konsep pada materi tatanama senyawa dan persamaan reaksi yang diukur dari pencapaian indikator, ditentukan dengan rumus:

Penguasaan konsep $=\frac{\sum \text { persentase penguasaan konsep per indikator }}{\sum \text { indikator }}$

\section{HASIL PENELITIAN DAN PEMBAHASAN}

Hasil jawaban siswa kemudian diolah sebagai data penguasaan konsep siswa. Butir soal pada tes uraian mewakili setiap konsep-konsep pada materi tatanama senyawa dan persamaan reaksi, dimana butir soal memiliki kriteria penskoran. Total skor yang didapatkan siswa dikonversikan dalam bentuk persentase penguasaan dan kemudian diklasifikasikan kedalam tingkat penguasaan siswa. Penguasaan konsep siswa pada materi tatanama senyawa dan persamaan reaksi disajikan pada Tabel 2.

Tabel 2 menunjukkan bahwa penguasaan konsep siswa pada materi tatanama senyawa dan persamaan reaksi terbilang cukup dengan rata-rata persantase penguasaan konsep sebesar $74.18 \%$. Penguasaan konsep siswa ditinjau dari 4 indikator, dimana penguasaan konsep siswa pada indikator 1 menuliskan rumus kimia suatu senyawa, indikator 2 menuliskan nama senyawa anorganik dan senyawa organik, indikator 3 menuliskan rumus kimia senyawa anorganik sederhana dan senyawa organik sederhana, dan indikator 4 menjelaskan bagianbagian dari suatu persamaan reaksi.

Tabel 2. Kategori Penguasaan Konsep Siswa Pada Materi Tatanama Senyawa dan Persamaan Reaksi

\begin{tabular}{llccc}
\hline \multicolumn{1}{c}{ Indikator } & \multicolumn{1}{c}{ Sub Indikator } & $\begin{array}{c}\text { Butir } \\
\text { Soal }\end{array}$ & $\begin{array}{c}\text { Penguasaan } \\
\text { Konsep }(\%)\end{array}$ & Kategori \\
\hline $\begin{array}{l}\text { Menuliskan } \\
\text { rumus kimia } \\
\text { suatau senyawa }\end{array}$ & $\begin{array}{l}\text { Menuliskan rumus } \\
\text { molekul }\end{array}$ & 1 & 81,66 & Tinggi \\
& $\begin{array}{l}\text { Menuliskan rumus } \\
\text { empiris }\end{array}$ & 2 & 93,33 & Sangat Tinggi \\
$\begin{array}{l}\text { Menuliskan } \\
\text { nenuliskan nama } \\
\text { anorganik dan }\end{array}$ & $\begin{array}{l}\text { senyawa biner non } \\
\text { senyawa } \\
\text { organik } \\
\text { berdasarkan } \\
\text { aturan IUPAC }\end{array}$ & 3 & 67,78 & Tinggi \\
& $\begin{array}{l}\text { Menuliskan nama non logam } \\
\text { senyawa biner logam } \\
\text { dan non logam }\end{array}$ & 4 & 76,67 & Tinggi \\
& $\begin{array}{l}\text { Menuliskan nama } \\
\text { senyawa poliatom } \\
\text { Menuliskan nama }\end{array}$ & 5 & 50,00 & Sedang \\
& $\begin{array}{l}\text { senyawa asam } \\
\text { Menuliskan nama } \\
\text { senyawa basa }\end{array}$ & 7 & 83,33 & Tinggi
\end{tabular}




\begin{tabular}{|c|c|c|c|c|}
\hline Indikator & Sub Indikator & $\begin{array}{l}\text { Butir } \\
\text { Soal }\end{array}$ & $\begin{array}{l}\text { Penguasaan } \\
\text { Konsep (\%) }\end{array}$ & Kategori \\
\hline & $\begin{array}{l}\text { Menuliskan nama } \\
\text { senyawa organik }\end{array}$ & 8 & 82,22 & Tinggi \\
\hline \multirow{2}{*}{$\begin{array}{l}\text { Menuliskan } \\
\text { rumus kimia } \\
\text { senyawa } \\
\text { anorganik } \\
\text { sederhana dan } \\
\text { senyawa } \\
\text { organik } \\
\text { sederhana }\end{array}$} & $\begin{array}{l}\text { Menuliskan rumus kimia } \\
\text { senyawa anorganik } \\
\text { sederhana }\end{array}$ & 9 & 85,83 & Tinggi \\
\hline & $\begin{array}{l}\text { Menuliskan rumus kimia } \\
\text { senyawa organik } \\
\text { sederhana }\end{array}$ & 10 & 83,33 & Tinggi \\
\hline \multirow{4}{*}{$\begin{array}{l}\text { Menjelaskan } \\
\text { bagian-bagian } \\
\text { dari suatu } \\
\text { persamaan } \\
\text { reaksi }\end{array}$} & $\begin{array}{l}\text { Menentukan senyawa } \\
\text { produk dan reaktan dari } \\
\text { suatu reaksi }\end{array}$ & 11 & 53,33 & Sedang \\
\hline & $\begin{array}{l}\text { Menjelaskan pengertian } \\
\text { produk dan reaktan }\end{array}$ & 12 & 51,67 & Sedang \\
\hline & $\begin{array}{l}\text { Menuliskan persamaan } \\
\text { reaksi dari pernyataan } \\
\text { suat reaksi kimia }\end{array}$ & 13 & 41,67 & Rendah \\
\hline & $\begin{array}{l}\text { Menyetarakan suat } \\
\text { persamaan reaksi kimia }\end{array}$ & 14 & 45,00 & Rendah \\
\hline \multicolumn{3}{|c|}{ Rata-rata penguasaan konsep (\%) } & 74,18 & Tinggi \\
\hline
\end{tabular}

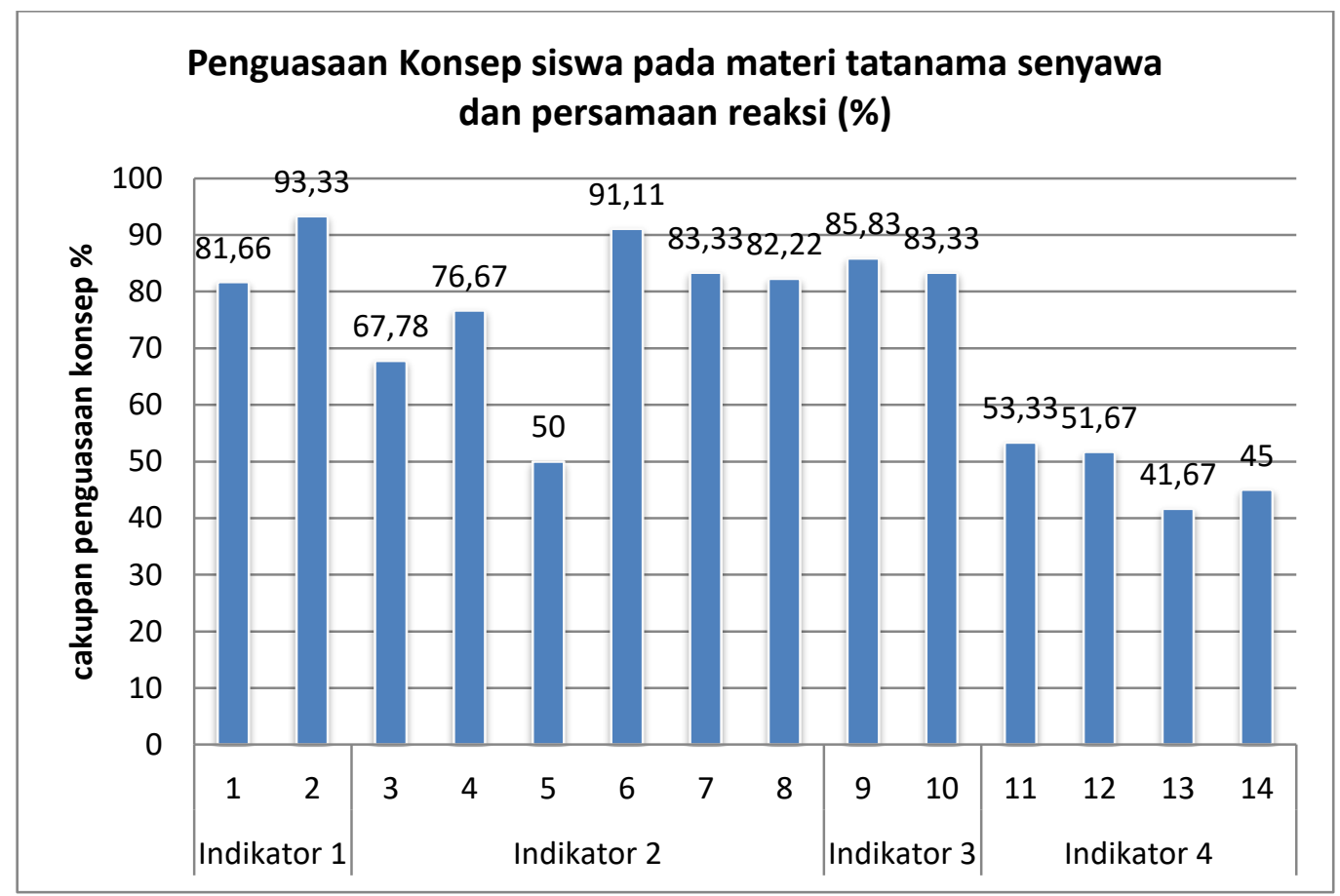

Gambar 1. Grafik Capaian Penguasaan Konsep Siswa Pada Materi Tatanama Senyawa dan Persamaan Reaksi. 
Grafik 1 menunjukkan bahwa capaian penguasaan konsep siswa pada indikator 1 telah memenuhi KKM dengan rata-rata skor sebesar 87\% dimana KKM sekolah tersebut sebesar 79, indikator 2 belum memenuhi KKM yang ditentukan sekolah dengan rata-rata skor sebesar $75,18 \%$, indiktor 3 telah memenuhi KKM sekolah dengan rata-rata skor sebesar $84,58 \%$, dan indikator 4 belum memenuhi KKM sekolah dengan rata-rata skor sebesar 47,92\%.

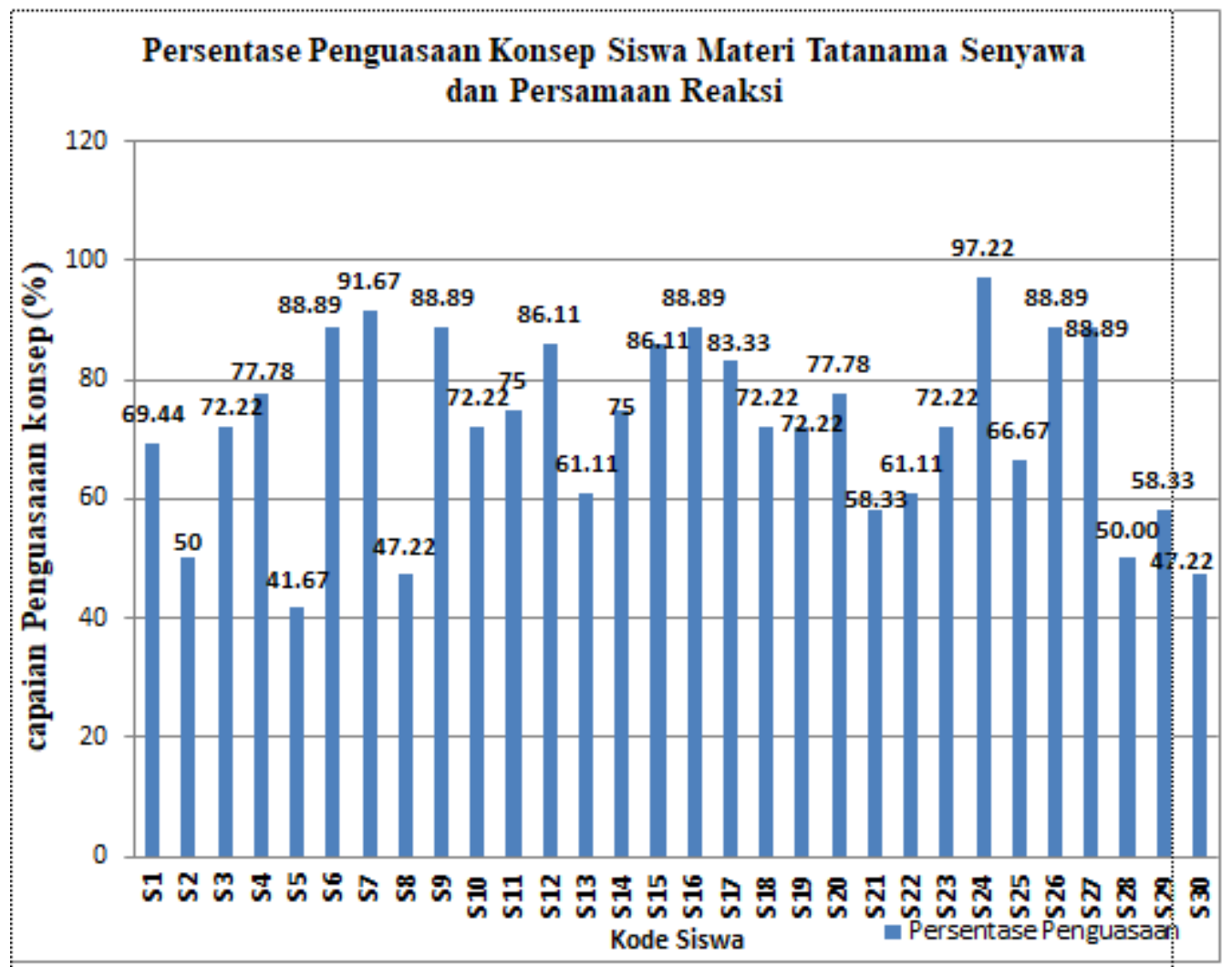

Gambar 2. Grafik Persentase penguasaan konsep siswa materi tatanama senyawa dan persamaan reaksi.

Hasil penguasaan konsep tatanama senyawa dan persamaan reaksi masing-masing siswa pada grafik 2 menunjukan terdapat 10 siswa memperoleh nilai tuntas diantas KKM, dan sebagian 20 siswa memperoleh nilai dibawah KKM. Sebagaimana dipaparkan pada Grafik 2.

Rencana pelaksanan pembelajaran (RPP) yang diamati dan dianalisis adalah RPP yang dibuat oleh guru berdasarkan kurikulum 2013. Untuk menganalisis RPP tersebut digunakan pedoman seperti pada Tabel 3.

Tabel 3. Komponen Kelengkapan RPP yang Terpenuh dan Tidak Terpenuhi

\begin{tabular}{ll}
\hline No & \multicolumn{1}{c}{ Aspek Ya } \\
\hline 1 & Identitas Sekolah \\
& A. Satuan Pendidikan \\
& B. Kelas \\
& C. Semester \\
& D. Mata Pelajaran \\
& E. Materi Pokok
\end{tabular}

RPP
A. Satuan Pendidikan
B. Kelas
D. Mata Pelajaran
E. Materi Pokok 


\begin{tabular}{|c|c|c|}
\hline No & Aspek Yang Diamati & RPP \\
\hline & F. Alokasi Waktu & $\sqrt{ }$ \\
\hline \multirow[t]{5}{*}{2} & Kompetensi Inti & - \\
\hline & KI 1 & - \\
\hline & KI 2 & - \\
\hline & KI 3 & - \\
\hline & KI 4 & - \\
\hline 3 & Kompetensi Dasar & $\sqrt{ }$ \\
\hline 4 & $\begin{array}{l}\text { Indikator } \\
\text { Indar }\end{array}$ & $\sqrt{ }$ \\
\hline 5 & Tujuan Pembelajaran & $\sqrt{ }$ \\
\hline 6 & Materi Pembelajaran & - \\
\hline 7 & Metode Pembelajaran & $\sqrt{ }$ \\
\hline 8 & Media Pembelajaran & $\sqrt{ }$ \\
\hline 9 & Alat dan Bahan & . \\
\hline 10 & Sumber Belajar & $\sqrt{ }$ \\
\hline 11 & Rencana Kegiatan Pembelajaraan & $\sqrt{ }$ \\
\hline & Kegiatan pendahuluan/awal & $\sqrt{ }$ \\
\hline & 1) Mengkondisikan peserta didik & $\sqrt{ }$ \\
\hline & $\begin{array}{l}\text { 2) Mengkaitkan materi sebelumnya dengan } \\
\text { materi yang akan dipelajari }\end{array}$ & $\sqrt{ }$ \\
\hline & 3) Menyampaikan tujuan pembelajaran & $\sqrt{ }$ \\
\hline & Kegiatan inti & $\sqrt{ }$ \\
\hline & 1) Mengamati & $\sqrt{ }$ \\
\hline & 2) Menanya & $\sqrt{ }$ \\
\hline & 3) Mengumpulkan data & $\sqrt{ }$ \\
\hline & 4) Mengasosiasikan & $\sqrt{ }$ \\
\hline & 5) Mengkomunikasikan & $\sqrt{ }$ \\
\hline & Kegiatan Penutup & $\sqrt{ }$ \\
\hline & 1) Meninjau kembali & $\sqrt{ }$ \\
\hline & 2) Mengevaluasi & $\sqrt{ }$ \\
\hline & 3) Tindak lanjut & $\sqrt{ }$ \\
\hline 12 & Penilaian & $\sqrt{ }$ \\
\hline & A Jenis/teknik penilaian & $\sqrt{ }$ \\
\hline & B Bentuk instrumen dan instrument & $\sqrt{ }$ \\
\hline & C Pedoman penskoran & - \\
\hline
\end{tabular}

Keterangan : $(\sqrt{ })=$ Terpenuhi

$$
(-)=\text { Tidak terpenuhi }
$$

Berdasarkan data analisis komponen isi RPP guru, bahwa hasil analisis RPP tersebut secara umum isinya telah sesuai seperti pada aspek yang diamati. Adapun pada penelitian ini, secara spesifik memperhatikan pada aspek keterkaitan KI, KD, indikator pencapaian kompetensi, tujuan pembelajaran, materi pembelajaran, serta model pembelajaran yang digunakan dalam pembuatan soal-soal tes penguasaan konsep. 
Tabel 4. Tabel Kesesuaian KD, IPK, Tujuan Pembelajaran dan Materi Pembelajaran

\begin{tabular}{|c|c|c|c|}
\hline KD & $\begin{array}{c}\text { Indikator } \\
\text { Pencapaian } \\
\text { Kompetensi }\end{array}$ & Tujuan Pembelajaran & $\begin{array}{c}\text { Materi } \\
\text { Pembelajaran }\end{array}$ \\
\hline $\begin{array}{l}3.9 \text { menentukan } \\
\text { bialngan oksidasi unsur } \\
\text { untuk mengidentifikasi } \\
\text { reaksi reduksi dan } \\
\text { oksidasi serta penamaan } \\
\text { senyawa }\end{array}$ & $\begin{array}{l}\text { 3.9.1 Mengidentifika } \\
\text { si nama } \\
\text { senyawa } \\
\text { menurut } \\
\text { IUPAC. }\end{array}$ & $\begin{array}{l}\text { 1. Menuliskan nama } \\
\text { senyawa } \\
\text { anorganik } \\
\text { sederhana } \\
\text { berdasarkan } \\
\text { tatanama IUPAC. } \\
\text { 2. Menuliskan nama } \\
\text { senyawa organik } \\
\text { seder hana } \\
\text { berdasarkan } \\
\text { tatanama IUPAC. } \\
\text { 3. Menuliskan rumus } \\
\text { kimia senyawa an } \\
\text { organik sederhana } \\
\text { berdasarkan } \\
\text { tatanama IUPAC. } \\
\text { 4. Menuliskan rumus } \\
\text { kimia senyawa } \\
\text { organik sederhana } \\
\text { berdasarkan } \\
\text { IUPAC }\end{array}$ & $\begin{array}{l}\text { Tatanama } \\
\text { senyawa }\end{array}$ \\
\hline $\begin{array}{l}\text { 3.10 Menerapkan } \\
\text { hukum-hukum dasar } \\
\text { kimia, konsep massa } \\
\text { molekul relatif, } \\
\text { persamaan kimia, } \\
\text { konsep mol, dan kadar } \\
\text { zat untuk } \\
\text { menyelesaikan } \\
\text { perhitungan kimia }\end{array}$ & $\begin{array}{l}3.10 .1 \\
\text { Menjelaskan } \\
\text { bagian-bagian dari } \\
\text { suatu persamaan } \\
\text { reaksi }\end{array}$ & persamaan reaksi & $\begin{array}{l}\text { Persamaan } \\
\text { Reaksi }\end{array}$ \\
\hline
\end{tabular}

Tujuan utama dari penelitian ini adalah untuk mendiskripsikan penguasaan konsep tatanama senyawa dan persamaan reaksi pada siswa. Hasil penelitian menunjukan bahwa rata-rata penguasaan siswa adalah sebesar $74.18 \%$ pada materi tatanama senyawa dan persamaan reaksi.

Kemampuan siswa dalam menuliskan rumus molekul suatu senyawa ditunjukan pada Tabel 2 sebesar $81,66 \%$ berada pada kategori tinggi. Berikut disajikan Tabel 5 tentang perolehan jumlah skor siswa yang benar setiap kategori pada butir soal 1 berdasarkan pola jawaban siswa yaitu mendiskripsikan menuliskan rumus molekul. 


\section{Tabel 5. Distribusi Capaian Siswa Pada Butir Soal 1}

\begin{tabular}{lcccc}
\hline \multirow{2}{*}{ Kategori Penguasaan } & \multirow{2}{*}{ Jumlah Siswa } & \multicolumn{3}{c}{ Jumlah Skor } \\
\cline { 3 - 5 } & & 0 & $\mathbf{1}$ & $\mathbf{2}$ \\
\hline Sangat Tinggi & 9 & - & 1 & 8 \\
Tinggi & 12 & - & 4 & 8 \\
Sedang & 9 & 2 & 2 & 5 \\
Jumlah siswa & $\mathbf{3 0}$ & $\mathbf{2}$ & $\mathbf{7}$ & $\mathbf{2 1}$ \\
Persentase (\%) & $\mathbf{1 0 0}$ & $\mathbf{6 . 6 6 \%}$ & $\mathbf{2 3 . 3 3 \%}$ & $\mathbf{7 0 \%}$ \\
\hline
\end{tabular}

Kemampuan siswa dalam menuliskan rumus empiris suatu senyawa ditunjukan pada Tabel 2 sebesar 93,33\% berada pada kategori sangat tinggi. Berikut disajikan Tabel 6 tentang perolehan jumlah skor siswa yang benar setiap kategori pada butir soal 2 berdasarkan pola jawaban siswa yaitu menuliskan rumus empiris.

\section{Tabel 6. Distribusi Capaian Pada Butir Soal 2}

\begin{tabular}{cccccc}
\hline \multirow{2}{*}{ Kategori Penguasaan } & \multirow{2}{*}{ Jumlah Siswa } & \multicolumn{5}{c}{ Jumlah Skor } \\
\cline { 3 - 6 } & & 0 & 1 & 2 & 3 \\
\hline Sangat Tinggi & 9 & - & - & - & 9 \\
Tinggi & 12 & - & - & - & 12 \\
Sedang & 9 & 2 & 2 & 5 & - \\
Jumlah & $\mathbf{3 0}$ & $\mathbf{2}$ & $\mathbf{2}$ & $\mathbf{5}$ & $\mathbf{2 1}$ \\
Persentase $(\%)$ & $\mathbf{1 0 0}$ & $\mathbf{6 . 6 6}$ & $\mathbf{6 . 6 6}$ & $\mathbf{1 6 . 6 6}$ & $\mathbf{7 0}$ \\
\hline
\end{tabular}

Tabel 6 memaparkan bahwa sebesar 6,66\% siswa memperoleh skor 0 artinya siswa belum mampu menuliskan rumus empiris suatu senyawa dengan benar, sebesar $6,66 \%$ siswa memperoleh skor 1 artinya siswa mampu menuliskn rumus empiris 1 senyawa dengan benar, sebesar 16,66\% siswa memperoleh skor 2 artinya siswa mampu menuliskan rumus empiris 2 senyawa dengan benar, dan sebesar $70 \%$ siswa mampu menuliskan rumus empris 3 senyawa dengan benar.

Kemampuan siswa dalam menuliskan nama senyawa biner non logam dan non logam ditunjukan pada Tabel 2 sebesar 67,78\% berada pada kategori tinggi. Berikut disajikan Tabel 7 tentang perolehan jumlah skor siswa yang benar setiap kategori pada butir soal 3 berdasarkan pola jawaban siswa yaitu menuliskan nama senyawa biner non logam dan non logam.

Tabel 7. Distribusi Capaian Pada Butir Soal 3

\begin{tabular}{cccccc}
\hline Kategori & Jumlah Siswa & \multicolumn{5}{l}{ Jumlah Skor } \\
\cline { 3 - 5 } Penguasaan & & 0 & 1 & 2 & 3 \\
\hline Sangat Tinggi & 9 & - & - & 3 & 6 \\
Tinggi & 12 & - & 1 & 7 & 4 \\
Sedang & 9 & 4 & 1 & 3 & 1 \\
Jumlah & $\mathbf{3 0}$ & $\mathbf{4}$ & $\mathbf{2}$ & $\mathbf{1 3}$ & $\mathbf{1 1}$ \\
Pesentase (\%) & $\mathbf{1 0 0}$ & $\mathbf{1 3 . 3 3}$ & $\mathbf{6 . 6 6}$ & $\mathbf{4 3 . 3 3}$ & $\mathbf{3 6 . 6 6}$ \\
\hline
\end{tabular}

Tabel 7 memaparkan bahwa sebesar 13,33\% memperoleh skor 0 artinya siswa belum bisa menuliskan nama senyawa dengan benar, sebesar 6,66\% memperoleh skor 1 artinya siswa bisa menuliskan nama 1 senyawa dengan benar namun pada 
hal skor ini siswa belum dapat dikatakan memiliki penguasaan pada menuliskan nama senyawa biner dengan benar, sebesar $43.33 \%$ memperoleh skor 2 artinyawa siswa bisa menuliskan nama 2 senyawa dengan benar pada hal siswa ini sudah dapat dikatakan memiliki penguasaan pada menuliskan nama senyawa dengan baik, dan sebesar 36,66\% siswa memperoleh skor 3 artinya siswa bisa menuliskan nama 3 senyawa dengan benar.

Kemampuan siswa dalam menuliskan nama senyawa biner logam dan non logam yaitu sebesar 76,67\% berada pada kategori tinggi. Berikut disajikan tabel 8 tentang perolehan jumlah skor siswa yang benar setiap kategori pada butir soal 4 berdasarkan pola jawaban siswa yaitu menuliskan nama senyawa biner logam dan non logam.

\section{Tabel 8. Distribusi Capaian Siswa Pada Butir Soal 4}

\begin{tabular}{cccccc}
\hline \multirow{2}{*}{ Kategori Penguasaan } & \multirow{2}{*}{ Jumlah Siswa } & \multicolumn{4}{c}{ Jumlah Skor } \\
\cline { 3 - 6 } & & 0 & 1 & 2 & 3 \\
\hline Sangat Tinggi & 9 & - & - & - & 9 \\
Tinggi & 12 & - & 3 & 2 & 7 \\
Sedang & 9 & 1 & 4 & 2 & 2 \\
Jumlah & $\mathbf{3 0}$ & $\mathbf{1}$ & $\mathbf{7}$ & $\mathbf{4}$ & $\mathbf{1 8}$ \\
Persentase (\%) & $\mathbf{1 0 0}$ & $\mathbf{3 . 3 3}$ & $\mathbf{2 3 . 3 3}$ & $\mathbf{1 3 . 3 3}$ & $\mathbf{6 0}$ \\
\hline
\end{tabular}

Berdasarkan Tabel 8 memaparkan sebesar 3,33\% siswa memperoleh skor 0 artinya siswa tersebut tidak mampu menuliskan nama 3 senyawa biner logam dan non logam dengan benar, sebesar 23,33\% siswa memperoleh skor 1 artinya siswa tersebut mampu menuliskan 1 senyawa biner logam dan non logam dengan benar, dan sebesar $13.33 \%$ siswa memperoleh skor 2 yang artinya siswa tersebut mampu menuliskan 2 senyawa biner logam dan non logam dengan benar, dan sebesar $60 \%$ siswa memperoleh skor 3 yang artinya siswa tersebut mampu menuliskan 3 senyawa biner logam dan non logam.

Kemampuan siswa dalam menuliskan nama senyawa poliatom yaitu sebesar 50,00\% berada pada kategori sedang. Berikut disajikan Tabel 9 tentang perolehan jumlah skor siswa setiap kategori pada butir soal 5.

\section{Tabel 9. Ditribusi Capaian Siswa pada Butir Soal 5}

\begin{tabular}{cccccc}
\hline \multirow{2}{*}{ Kategori penguasaan } & \multirow{2}{*}{ Jumlah siswa } & \multicolumn{5}{c}{ Jumlah skor } \\
\cline { 3 - 6 } & & 0 & 1 & 2 & 3 \\
\hline Sangat Tinggi & 9 & - & 1 & 6 & 2 \\
Tinggi & 12 & 3 & 2 & 5 & 2 \\
Sedang & 9 & 5 & 1 & 2 & 1 \\
Jumlah & $\mathbf{3 0}$ & $\mathbf{8}$ & $\mathbf{4}$ & $\mathbf{1 3}$ & $\mathbf{5}$ \\
Persentase & $\mathbf{1 0 0}$ & $\mathbf{2 6 . 6 7}$ & $\mathbf{1 3 . 3 3}$ & $\mathbf{4 3 . 3 3}$ & $\mathbf{1 6 . 6 6}$ \\
\hline
\end{tabular}

Berdasarkan Tabel 9 diketahui bahwa sebesar 26,67\% siswa memperoleh skor 0 artinya siswa tersebut tidak mampu menuliskan nama 3 senyawa poliatom dengan benar, sebesar 13,33\% siswa memperoleh skor 1 artinya siswa tersebut mampu menuliskan 1 senyawa poliatom dengan benar, dan sebesar 43,33\% siswa memperoleh skor 2 yang artinya siswa tersebut mampu menuliskan 2 senyawa 
poliatom dengan benar, dan sebesar $16,66 \%$ siswa memperoleh skor 3 yang artinya siswa tersebut mampu menuliskan 3 senyawa poliatom.

Kemampuan siswa dalam menuliskan nama senyawa asam sebesar $91,11 \%$ berada pada kategori sangat tinggi. Berikut disajikan Tabel 10 tentang perolehan jumlah skor siswa yang benar setiap kategori pada butir soal 6 berdasarkan pola jawaban siswa yaitu menuliskan nama senyawa asam.

\section{Tabel 10. Distribusi Capaian Siswa Pada Butir Soal 6}

\begin{tabular}{cccccc}
\hline \multirow{2}{*}{ Kategori penguasaan } & \multirow{2}{*}{ Jumlah siswa } & \multicolumn{4}{c}{ Jumlah skor } \\
\cline { 3 - 6 } & & $\mathbf{0}$ & $\mathbf{1}$ & 2 & 3 \\
\hline Sangat Tinggi & 9 & - & - & - & 9 \\
Tinggi & 9 & - & - & 3 & 9 \\
Sedang & $\mathbf{3 0}$ & - & 2 & 1 & 6 \\
Jumlah & $\mathbf{2}$ & $\mathbf{4}$ & $\mathbf{2 4}$ \\
Persentase & $\mathbf{1 0}$ & - & $\mathbf{6 . 6 7}$ & $\mathbf{1 3 . 3 3}$ & $\mathbf{8 0}$ \\
\hline
\end{tabular}

Berdasarkan Tabel 10 diketahui bahwa sebesar 6,67\% siswa memperoleh skor 1 artinya siswa tersebut mampu menuliskan 1 senyawa asam dengan benar, dan sebesar 13,33\% siswa memperoleh skor 2 yang artinya siswa tersebut mampu menuliskan 2 senyawa asam dengan benar, dan sebesar $80 \%$ siswa memperoleh skor 3 yang artinya siswa tersebut mampu menuliskan 3 senyawa asam.

Kemampuan siswa dalam menuliskan nama senyawa basa sebesar $83,33 \%$ berada pada kategori tinggi. Berikut disajikan Tabel 11 tentang perolehan jumlah skor siswa yang benar setiap kategori pada butir soal 7 berdasarkan pola jawaban siswa yaitu menuliskan nama senyawa basa.

\section{Tabel 11. Distribusi Capaian Siswa pada Butir Soal 7}

\begin{tabular}{cccccc}
\hline \multirow{2}{*}{ Kategori Penguasaan } & \multirow{2}{*}{ Jumlah Siswa } & \multicolumn{4}{c}{ Jumlah Skor } \\
\cline { 3 - 6 } & 9 & $\mathbf{0}$ & $\mathbf{1}$ & 2 & 3 \\
\hline Sangat Tinggi & 12 & - & - & - & 9 \\
Tinggi & 9 & 1 & 2 & - & 6 \\
Sedang & $\mathbf{3 0}$ & $\mathbf{1}$ & $\mathbf{5}$ & $\mathbf{2}$ & $\mathbf{2 2}$ \\
Jumlah & $\mathbf{1 0 0}$ & $\mathbf{3 . 3 3}$ & $\mathbf{1 6 . 6 6}$ & $\mathbf{6 . 6 7}$ & $\mathbf{7 3 . 3 3}$ \\
Persentase (\%) & & & &
\end{tabular}

Berdasarkan Tabel 11 diketahui bahwa sebesar 3,33\% siswa memperoleh skor 0 artinya siswa tersebut tidak mampu menuliskan nama 3 senyawa basa dengan benar, sebesar $16,66 \%$ siswa memperoleh skor 1 artinya siswa tersebut mampu menuliskan 1 senyawa basa dengan benar, dan sebesar 6,67\% siswa memperoleh skor 2 yang artinya siswa tersebut mampu menuliskan 2 senyawa basa dengan benar, dan sebesar 73,33\% siswa memperoleh skor 3 yang artinya siswa tersebut mampu menuliskan 3 senyawa basa.

Kemampuan siswa dalam menuliskan nama senyawa basa sebesar 82,22\% berada pada kategori tinggi. Berikut disajikan Tabel 12 tentang perolehan jumlah skor siswa yang benar setiap kategori pada butir soal 4 berdasarkan pola jawaban siswa yaitu menuliskan nama senyawa organik. 


\section{Tabel 12. Distribusi Capaian Siswa Pada Butir Soal 8}

\begin{tabular}{cccccc}
\hline \multirow{2}{*}{ Kategori Penguasaan } & \multirow{2}{*}{ Jumlah Siswa } & \multicolumn{4}{c}{ Jumlah Skor } \\
\cline { 3 - 6 } & & $\mathbf{0}$ & 1 & 2 & 3 \\
\hline Sangat Tinggi & 9 & - & - & 4 & 5 \\
Tinggi & 12 & - & - & 5 & 7 \\
Sedang & 9 & 1 & - & 4 & 4 \\
Jumlah & $\mathbf{3 0}$ & $\mathbf{1}$ & - & $\mathbf{1 3}$ & $\mathbf{1 6}$ \\
Persentase & $\mathbf{1 0 0}$ & $\mathbf{3 . 3 3}$ & - & $\mathbf{4 3 . 3 3}$ & $\mathbf{5 3 . 3 3}$ \\
\hline
\end{tabular}

Berdasarkan Tabel 12 diketahui bahwa sebesar 3,33\% siswa memperoleh skor 0 artinya siswa tersebut tidak mampu menuliskan nama 3 senyawa organik dengan benar, sebesar $43.33 \%$ siswa memperoleh skor 2 artinya siswa tersebut mampu menuliskan 2 senyawa organik sederhana dengan benar, dan sebesar $53,33 \%$ siswa memperoleh skor 3 yang artinya siswa tersebut mampu menuliskan 3 senyawa organik sederhana dengan benar.

Kemampuan siswa dalam menuliskan rumus kimia senyawa anorganik sebesar 85,83\% berada pada kategori tinggi. Berikut disajikan Tabel 13 tentang perolehan jumlah skor siswa yang benar setiap kategori pada butir soal 9 berdasarkan pola jawaban siswa yaitu menuliskan rumus kimia senyawa anorganik.

Tabel 13. Distribusi Capaian Siswa Pada Butir Soal 9

\begin{tabular}{ccccccc}
\hline \multirow{2}{*}{ Kategori Penguasaan } & \multirow{2}{*}{ Jumlah Siswa } & \multicolumn{5}{c}{ Jumlah Skor } \\
\cline { 3 - 7 } & & $\mathbf{0}$ & $\mathbf{1}$ & 2 & 3 & 4 \\
\hline Sangat Tinggi & 9 & - & - & - & 5 & 4 \\
Tinggi & 12 & - & - & 1 & 3 & 8 \\
Sedang & 9 & - & - & 1 & 6 & 2 \\
Jumlah & $\mathbf{3 0}$ & - & - & $\mathbf{2}$ & $\mathbf{1 4}$ & $\mathbf{1 4}$ \\
Persentase & $\mathbf{1 0 0}$ & - & - & $\mathbf{6 . 6 7}$ & $\mathbf{4 6 . 6 6}$ & $\mathbf{4 6 . 6 6}$ \\
\hline
\end{tabular}

Berdasarkan Tabel 13 diketahui bahwa sebesar 6,67\% siswa memperoleh skor 2 artinya siswa tersebut mampu menuliskan 2 senyawa anorganik sederhana dengan benar, sebesar 46,66\% siswa memperoleh skor 3 artinya siswa tersebut mampu menuliskan 3 senyawa anorganik sederhana dengan benar, dan sebesar $46,66 \%$ siswa memperoleh skor 4 yang artinya siswa tersebut mampu menuliskan 4 senyawa anorganik sederhana dengan benar.

Kemampuan siswa dalam menuliskan rumus kimia senyawa organik yaitu sebesar 83,33\% berada pada kategori tinggi. Berikut disajikan Tabel 14 tentang perolehan jumlah skor siswa yang benar setiap kategori pada butir soal 10 berdasarkan pola jawaban siswa yaitu menuliskan rumus kimia senyawa organik.

\section{Tabel 14. Jumlah skor benar setiap kategori pada butir soal 10}

\begin{tabular}{cccc}
\hline \multirow{2}{*}{ Kategori Penguasaan } & \multirow{2}{*}{ Jumlah Siswa } & \multicolumn{2}{c}{ Jumlah Skor } \\
\cline { 3 - 4 } & & 0 & 1 \\
\hline Sangat Tinggi & 9 & - & 9 \\
Tinggi & 12 & 2 & 10 \\
Sedang & 9 & 3 & 6 \\
Jumlah & $\mathbf{3 0}$ & $\mathbf{5}$ & $\mathbf{2 5}$ \\
\hline
\end{tabular}




\begin{tabular}{llll} 
Persentase & 100 & $\mathbf{1 6 . 6 7}$ & $\mathbf{8 3 . 3 3}$ \\
\hline
\end{tabular}

Tabel 14 memaparkan bahwa sebesar $16,67 \%$ siswa memperoleh skor 0 artinya siswa belum bisa menuliskan rumus kimia senyawa organik sederhana dengan benar, dan sebesar 83,33\% siswa memperoleh skor 1 artinya siswa bisa menuliskan rumus kimia senyawa organik sederhana dengan benar, pada hal ini 30 orang siswa ini sudah dapat dikatakan memiliki penguasaan pada menuliskan rumus kimia senyawa organik sederhana dengan baik.

Kemampuan siswa dalam menentukan senyawa produk dan reaktan pada suatu reaksi sebesar 53,33\% berada pada kategori sedang. Berikut disajikan Tabel 15 tentang perolehan jumlah skor siswa yang benar setiap kategori pada butir soal 11 berdasarkan pola jawaban siswa yaitu menuliskan kelompok zat reaktan atau produk.

\section{Tabel 15. Distribusi Capaian Siswa Pada Butir Soal 11}

\begin{tabular}{ccccc}
\hline \multirow{2}{*}{ Kategori Penguasaan } & \multirow{2}{*}{ Jumlah Siswa } & \multicolumn{3}{c}{ Jumlah Skor } \\
\cline { 3 - 5 } & & 0 & 1 & 2 \\
\hline Sangat Tinggi & 9 & - & - & 9 \\
Tinggi & 12 & 6 & 2 & 4 \\
Sedang & 9 & 6 & 2 & 1 \\
Jumlah & $\mathbf{3 0}$ & $\mathbf{1 2}$ & $\mathbf{4}$ & $\mathbf{1 4}$ \\
Persentase & $\mathbf{1 0 0}$ & $\mathbf{4 0}$ & $\mathbf{1 3}$ & $\mathbf{4 7}$ \\
\hline
\end{tabular}

Tabel 15 diketahui bahwa perolehan skor 0 terdapat 12 orang siswa (40\%) belum bisa menuliskan kelompok zat reaktan dan produk dengan benar, perolehan skor 1 sebanyak 4 orang siswa (13\%) bisa menuliskan kelompok zat reaktan atau produk dengan benar, dan perolehan skor 2 sebanyak 14 orang siswa (47\%) bisa menuliskan menuliskan kelompok zat reaktan dan produk dengan benar pada hal ini 14 orang siswa ini sudah dapat dikatakan memiliki penguasaan pada menuliskan kelompok zat reaktan atau produk dengan baik.

Kemampuan siswa dalam menentukan senyawa produk dan reaktan pada suatu reaksi sebesar 51,67\% berada pada kategori sedang. Berikut disajikan Tabel 16 tentang perolehan jumlah skor siswa yang benar setiap kategori pada butir soal 12 berdasarkan pola jawaban siswa yaitu menuliskan penjelasan istilah reaktan atau produk.

\section{Tabel 16. Distribusi Capaian Siswa Pada Butir Soal 12}

\begin{tabular}{ccccc}
\hline \multirow{2}{*}{ Kategori penguasaan } & \multirow{2}{*}{ Jumlah siswa } & \multicolumn{4}{c}{ Jumlah skor benar } \\
\cline { 3 - 5 } & & 0 & 1 & 2 \\
\hline Sangat Tinggi & 9 & - & 1 & 8 \\
Tinggi & 12 & 4 & 5 & 3 \\
Sedang & 9 & 7 & 1 & 1 \\
Jumlah & $\mathbf{3 0}$ & $\mathbf{1 1}$ & $\mathbf{7}$ & $\mathbf{1 2}$ \\
Persentase (\%) & $\mathbf{1 0 0}$ & $\mathbf{3 6 . 6 6}$ & $\mathbf{2 3 . 3 3}$ & $\mathbf{4 0}$ \\
\hline
\end{tabular}

Tabel 16 memaparkan bahwa sebesar $36,66 \%$ siswa mendapatkan skor 0 artinya siswa belum bisa menuliskan penjelasan istilah reaktan dan produk dengan benar, sebesar 23,33\% memperoleha skor 1 artinya siswa bisa menuliskan 
penjelasan istilah reaktan atau produk dengan benar, dan sebesar $40 \%$ siswa memperoleh skor 2 artinya siswa bisa menuliskan penjelasan istilah reaktan dan produk dengan benar.

Kemampuan siswa dalam menuliskan persamaan reaksi dari suatu pernyataan reaksi kimia berada pada kategori rendah yaitu sebesar $41.67 \%$. Berikut disajikan Tabel 17 tentang perolehan jumlah skor siswa yang benar setiap kategori pada butir soal 13 berdasarkan pola jawaban siswa yaitu menuliskan persamaan reaksi dari pernyataan suatu reaksi kimia.

\section{Tabel 17. Distribusi Capaian Siswa Pada Butir Soal Soal 13}

\begin{tabular}{ccccc}
\hline \multirow{2}{*}{ Kategori Penguasaan } & \multirow{2}{*}{ Jumlah Siswa } & \multicolumn{3}{c}{ Jumlah Skor } \\
\cline { 3 - 5 } & & 0 & 1 & 2 \\
\hline Sangat Tinggi & 9 & - & 8 & 1 \\
Tinggi & 12 & - & 12 & - \\
Sedang & 9 & 6 & 3 & - \\
Jumlah & $\mathbf{3 0}$ & $\mathbf{6}$ & $\mathbf{2 3}$ & $\mathbf{1}$ \\
Persentse & $\mathbf{1 0 0}$ & $\mathbf{2 0}$ & $\mathbf{7 6 . 6 7}$ & $\mathbf{3 . 3 3}$ \\
\hline
\end{tabular}

Tabel 17 memaparkan bahwa sebesar 20\% siswa memperoleh skor 0 artinya siswa belum mampu menuliskan persamaan reaksi dari pernyataan suatu reaksi kimia dengan benar, sebesar $76.67 \%$ siswa memperoleh skor 2 artinya siswa bisa menuliskan persamaan reaksi dengan benar namun belum mampu menuliskan persamaan reaksi beserta fasa pada masing-masing senyawa, dan sebesar $3.33 \%$ siswa memperoleh skor 2 artinya siswa mampu menuliskan persamaan reaksi beserta fasa pada masing-masing senyawa dengan benar pada hal ini 1 orang siswa ini sudah dapat dikatakan memiliki penguasaan pada menuliskan persamaan reaksi dengan baik.

Kemampuan siswa dalam menyetarakan persamaan reaksi berada pada kategori rendah yaitu sebesar $45.00 \%$. Berikut disajikan Tabel 18 tentang perolehan jumlah skor siswa yang benar setiap kategori pada butir soal 14 berdasarkan pola jawaban siswa yaitu menyetarakan suatu persamaan reaksi.

\section{Tabel 18. Distribusi Capaian Siswa Pada Butir Soal 14}

\begin{tabular}{ccccc}
\hline \multirow{2}{*}{ Kategori penguasaan } & \multirow{2}{*}{ Jumlah siswa } & \multicolumn{4}{c}{ Jumlah skor } \\
\cline { 3 - 5 } & & 0 & 1 & 2 \\
\hline Sangat Tinggi & 9 & - & 3 & 6 \\
Tinggi & 12 & 6 & 2 & 4 \\
Sedang & 9 & 8 & 1 & - \\
Jumlah & $\mathbf{3 0}$ & $\mathbf{1 4}$ & $\mathbf{6}$ & $\mathbf{1 0}$ \\
Persentase (\%) & $\mathbf{1 0 0}$ & $\mathbf{4 6 . 6 7}$ & $\mathbf{2 0}$ & $\mathbf{3 3 . 3 3}$ \\
\hline
\end{tabular}

Tabel 18 memaparkan bahwa sebesar $46,67 \%$ siswa memperoleh skor 0 artinya siswa belum mampu menuliskan persamaan reaksi dengan benar, sebesar $20 \%$ siswa memperoleh skor 1 artinya siswa bisa menentukan nilai a,b, dan c dengan benar, dan sebesar $33.33 \%$ siswa memperoleh skor 2 artinya siswa bisa menentukan nilai $\mathrm{a}, \mathrm{b}$ dan $\mathrm{c}$ dengan benar dan menuliskan persamaan reaksi. 


\section{SIMPULAN}

Kesimpulan berdasarkan hasil penelitian, yaitu;Rata-rata penguasaan konsep siswa pada topik tatanama senyawa dan persamaan reaksi siswa yaitu sebesar $74.18 \%$ berada pada kategori tinggi. Penguasaan konsep siswa terbagi kedalam 3 (tiga) kategori yaitu sangat tinggi, tinggi, dan sedang. Siswa pada kategori sangat tinggi berjumlah 9 siswa, siswa pada kategori tinggi berjumlah 12 siswa. Siswa pada kategori sedang berjumlah 9 siswa. Siswa mampu menuliskan rumus molekul dan rumus empiris suatu senyawa dengan penguasaan konsep sebesar $81.66 \%$ dan berada pada kategori tinggi. Siswa mampu menuliskan nama senyawa anorganik (senyawa biner, senyawa poliatom, senyawa asam, dan senyawa basa) dan senyawa organik dengan penguasaan konsep sebesar $75.18 \%$ dan berada pada kategori tinggi. Siswa mampu menuliskan rumus kimia senyawa anorganik sederhana dan senyawa organik sederhana dengan penguasaan konsep sebesar $84.58 \%$ berada pada kategori tinggi. Siswa mampu menjelaskan bagianbagian dari suatu persamaan reaksi dengan penguasaan konsep berada pada kategori rendah.

\section{DAFTAR PUSTAKA}

Asi, N.B. 2018. Dimensi Pengetahuan Dan Tingkat Berpikir Pada Pembelajaran Kimia. Jurnal Ilmiah Kanderang Tingang. 9, 2 (Des. 2018), 103-113.

Aulia, Rakhmawati. (2014). Visualisasi Siswa Kelas XI IPA SMAN 4 Palangka Raya Dalam Memahami Persamaan Reaksi Kimia Pada Ketiga Level Representasi (Makroskopik, Mikroskopik, Dan Simbolik). Palangka Raya : Universitas Palangka Raya.

Ghalib, Achmad Kholish. 2009. Buku Pintar Kimia. Jogjakarta : Power Books (ihdina)

Helfiana. Mita. 2016. Penguasaan Konsep Pada Materi Tata Nama Senyawa Melalui Pembelajaran Berbasis Inkuiri Siswa Kelas $X$ Sman I Labuhanhaji. Darussalam-Banda Aceh: Universitas Islam Negeri ArRaniry.

Hengki. 2015. Penguasaan Konsep Tata Nama Senyawa Biner dan Poliatomik Dalam Pembelajaran Menggunakan Metode Diskusi Berbantuan LKSDeduktif Pada Siswa Kelas X SMK Negeri 1 Palangka Raya Tahun Ajaran 2014/2015. Palangka Raya : Universitas Palangka Raya.

Oktavia, H., Sadiana, I.M. and Asi, N.B. 2019. Profil Penguasaan Konsep Sistem Periodik Unsur pada Siswa Kelas X MIPA SMA Negeri 1 Palangka Raya Tahun Ajaran 2018/2019. Jurnal Ilmiah Kanderang Tingang. 10, 2 (Des. 2019), 321-340.

Sulistyowati, Tri \& Poedjiastoeti, Sri. 2013. Kelayakan Multimedia Interaktif Berbasis Intertekstual Pada Materi Reaksi Kimia Untuk Kelas X SMA. Unesa Journal of Chemical Education ISSN : 2252-9454 Vol.2 No.3 pp.57-63. 